\title{
LENGTH-WEIGHT RELATIONS FOR 29 FISH SPECIES FROM HOMA LAGOON, AEGEAN SEA, TURKEY
}

\author{
Deniz ACARLI ${ }^{1 *}$, Ali KARA ${ }^{2}$, and Bahar BAYHAN ${ }^{3}$ \\ ${ }^{1}$ Çanakkale Onsekiz Mart University, Gökçeada School of Applied Sciences, \\ Department of Fisheries Technology, 17760 Çanakkale, Turkey \\ ${ }^{2}$ Ege University, Faculty of Fisheries, Department of Fishing and Processing Technology, 35100 Izmir, Turkey \\ ${ }^{3}$ Ege University, Faculty of Fisheries, Department of Hydrobiology, 35100 Izmir, Turkey
}

Acarli D., Kara A., Bayhan B. 2014. Length-weight relations for 29 fish species from Homa Lagoon, Aegean Sea, Turkey. Acta Ichthyol. Piscat. 44 (3): 249-257.

\begin{abstract}
In the course of the presently reported study, covering the Homa Lagoon, Izmir Bay, Turkey, we collected a total of 2690 fish specimens belonging to 15 families and representing 29 species: Anguilla anguilla (Linnaeus, 1758); Atherina hepsetus Linnaeus, 1758; Atherina boyeri Risso, 1810; Belone belone (Linnaeus, 1761); Blennius ocellaris Linnaeus, 1758; Sardina pilchardus (Walbaum, 1792); Aphanius fasciatus (Valenciennes, 1821); Engraulis encrasicolus (Linnaeus, 1758); Gobius niger Linnaeus, 1758; Pomatoschistus marmoratus (Risso, 1810); Pomatoschistus minutus (Pallas, 1770); Zosterisessor ophiocephalus (Pallas, 1814); Dicentrarchus labrax (Linnaeus, 1758); Chelon labrasus (Risso, 1827); Liza aurata (Risso, 1810); Liza ramada (Risso, 1827); Liza saliens (Risso, 1810); Mugil cephalus Linnaeus, 1758; Mullus barbatus Linnaeus, 1758; Mullus surmuletus Linnaeus, 1758; Syngnathus acus Linnaeus, 1758; Syngnathus typhle Linnaeus, 1758; Diplodus annularis (Linnaeus, 1758); Diplodus vulgaris (Geoffroy Saint-Hilaire, 1817); Lithognathus mormyrus (Linnaeus, 1758); Sarpa salpa (Linnaeus, 1758); Sparus aurata Linnaeus, 1758; Platichthys flesus (Linnaeus, 1758); Solea solea (Linnaeus, 1758). The fish were weighed, and measured and their length-weight relations were determined. Samples were collected during 2009-2010 using four different types of fishing gear (beach seine, fyke nets, barrier trap, and trammel nets; mesh size: 25,28 , and $30 \mathrm{~mm}$ ) that allowed both adult and juvenile specimens to be captured. Significant length-weight relations were found for all species. The exponent $b$ varied between 2.753 for Pomatoschistus marmoratus and 3.650 for Aphanius fasciatus (mean value = 3.115). The length-weight parameters of the same species may be different in the population because of feeding, reproduction activities and fishing etc. Therefore, we need to know length-weight relations of fish, which are captured in a given place in a certain period of time. Length-weight relations for 5 out of the 29 fish species are presented for the first time from Homa Lagoon in the Turkish Aegean Sea.
\end{abstract}

Keywords: LWR, fishing gear, coastal lagoon, Izmir Bay, Mediterranean Sea

Length-weight (LW) relations for fish were originally used to provide information on the condition of fish and determine whether somatic growth was isometric or allometric (Le Cren 1951, Tesch 1971, Ricker 1975). LW relations of fish are important because they allow:

- to estimate the condition of fish,

- to calculate biomass from the length values,

- to determine weight-at-age and convert growth-inlength equations to growth-in-weight ones, and

- to make interregional comparisons of life histories of certain species (Gonçalves et al. 1997, Froese and Pauly 1998, Moutopoulos and Stergiou 2002, Dulčić and Glamuzina 2006).
This study reports the parameters of the length-weight relations for 29 fish species collected from Homa Lagoon, Izmir Bay, Aegean Sea of Turkey: Anguilla anguilla (Linnaeus, 1758); Atherina hepsetus Linnaeus, 1758; Atherina boyeri Risso, 1810; Belone belone (Linnaeus, 1761); Blennius ocellaris Linnaeus, 1758; Sardina pilchardus (Walbaum, 1792); Aphanius fasciatus (Valenciennes, 1821); Engraulis encrasicolus (Linnaeus, 1758); Gobius niger Linnaeus, 1758; Pomatoschistus marmoratus (Risso, 1810); Pomatoschistus minutus (Pallas, 1770); Zosterisessor ophiocephalus (Pallas, 1814); Dicentrarchus labrax (Linnaeus, 1758); Chelon labrasus (Risso, 1827); Liza aurata (Risso, 1810); Liza ramada

\footnotetext{
* Correspondence: Dr. Deniz Acarlı, Çanakkale Onsekiz Mart Üniversitesi, Gökçeada Uygulamalı Bilimler Yüksekokulu, Balıkçılık Teknolojisi Bölümü, 17760 Çanakkale, Turkey, phone: (+90) 286 8872302/22, fax: (+90) 286 8872303, e-mail: (DA) denizacarli@comu.edu.tr, (AK) ali.kara@ege.edu.tr, (BB)bahar.bayhan@ege.edu.tr.
} 
(Risso, 1827); Liza saliens (Risso, 1810); Mugil cephalus Linnaeus, 1758; Mullus barbatus Linnaeus, 1758; Mullus surmuletus Linnaeus, 1758; Syngnathus acus Linnaeus, 1758; Syngnathus typhle Linnaeus, 1758; Diplodus annularis (Linnaeus, 1758); Diplodus vulgaris (Geoffroy Saint-Hilaire, 1817); Lithognathus mormyrus (Linnaeus, 1758); Sarpa salpa (Linnaeus, 1758); Sparus aurata Linnaeus, 1758; Platichthys flesus (Linnaeus, 1758); Solea solea (Linnaeus, 1758). Also length-weight relations for five fish species (Anguilla anguilla, Atherina hepsetus, Pomatoschistus marmoratus, Pomatoschistus minutus, and Platichthys flesus) are presented for the first time from Homa Lagoon in the Turkish Aegean Sea. We believe that the results of the presently reported study can be applied to fisheries management of the Homa Lagoon and also Izmir Bay.

Study area. The Homa Lagoon $\left(38^{\circ} 30^{\prime}-38^{\circ} 35^{\prime} \mathrm{N}\right.$, $26^{\circ} 48^{\prime}-26^{\circ} 53^{\prime} \mathrm{E}$ ) is situated in the north-eastern part of Izmir Bay, in the Menemen District $42 \mathrm{~km}$ away from the centre of the Izmir Metropolitan Municipality. The lagoon covers an area of $1200 \mathrm{ha}$, being $7.4 \mathrm{~km}$ long and $3 \mathrm{~km}$ wide. Its maximum depth is $1.8 \mathrm{~m}$, but many areas are shallow $(0.5-1 \mathrm{~m})$. The lagoon is separated from the see by a narrow sandspit. There are 6 canals allowing the water exchange between the sea and the lagoon. The widest canal is outfitted with a barrier trap designed to catch fish. For a detailed map of the lagoon see Bayhan and Acarli (2006). Surface water temperature varies from $28^{\circ} \mathrm{C}$ in September to $-2{ }^{\circ} \mathrm{C}$ in December with a yearly mean of $16^{\circ} \mathrm{C}$. Mean annual salinity is $31.9 \%$ with the highest of $44.4 \%$ and the lowest of $27 \%$ in November and April, respectively. The lagoon supports important commercial fisheries, including mullets (especially Liza saliens and Mugil cephalus), gilthead sea bream (Sparus aurata), sea bass (Dicentrarchus labrax), ell (Anguilla anguilla), and sole (Solea solea) in particular (Alpbaz and Kinacigil 1988, Bayhan and Acarli 2006, Acarl1 et al. 2009).

Data collection. Monthly field studies were performed between February 2009 and March 2010. Samplings were made using four different fishing gears: beach seine, fyke nets, barrier trap, and trammel nets of different mesh size (Table 1). The beach seine was used at day light with 6-7 hauls a day (monthly for a year). Fyke nets were set at dusk and picked up at dawn with a soak time of 10-14 h a day of every month. Barrier trap is generally set between the lagoon and the sea with a rectangular trap chamber composed of reed fences including the closure of canal with reed fences on both sides. Fish swim through a V-shape entrance into the trap and pass through a few sections as far as the final chambers, from where they are taken our with dip nets. As Katselis et al. (2003) reported, one of the most important types of exploitation is to use of barrier traps to catch fish during their seasonal or ontogenic offshore migration. The lagoon is an important nursery area and constitutes the fish feeding ground and therefore the local fishery benefits from fish migration related to feeding and reproduction. The sampling, using the barrier trap, was occasional and was performed either in the day light or overnight, between December and June (The trap was opened in December and closed in early June). Trammel nets were used overnight for a day, monthly. Fish were scared back into the nets and collected after being entangled.

Data analysis. Specimens caught were identified to species level, measured to the nearest $0.1 \mathrm{~cm}$ (total length, TL), and wet-weighed (total weight, TW) to the nearest $1 \mathrm{~g}$. The relation was established using linear regression analysis, TW vs. TL (log-transformed):

$$
\log (\mathrm{TW})=\log (a)+(b) \log (\mathrm{TL})
$$

where $a$ is the intercept of the regression curve (coefficient related to body form) and $b$ is the regression coefficient (exponent indicating isometric growth when equal to 3 ). The significance of the regression was assessed by ANOVA and the $b$-value for each species was tested to be significantly different from the isometric growth $(b=3)$ (Sokal and Rohlf 1981, Verdiell-Cubedo et al. 2006). All statistical analyses were evaluated at $P<0.05$ significance level.

A total of 2690 individuals was sampled during the study period. The LW relations of 29 fish species of 15 families are given in Table 2. Mugilidae and Sparidae were the most abundant families. Linear regressions were significant for all studied species $(P<0.05)$. The sample size ranged from 178 Aphanius fasciatus to 37 individuals for Syngnathus typhle.

Table 1

Fishing gear used in the presently reported study and their technical properties

\begin{tabular}{ll}
\hline Fishing gear & Description \\
\hline Beach seine & Wings length $25 \mathrm{~m}$, wing height $1.5 \mathrm{~m}$, bag length $5 \mathrm{~m}$, mouth width $3 \mathrm{~m}$, mouth height $1.5 \mathrm{~m}$
\end{tabular}

Fyke nets

Equipped with 3 funnels and 7 hoops, the first of which is D-shape; Every operation included 50 fyke nets of the same characteristics which were tied to one another used in a serial line; Mesh size of $12 \mathrm{~mm}$ were used to construct the netting; The leading net was $3 \mathrm{~m}$ long between the two fyke nets with a $12 \mathrm{~mm}$ mesh size

Barrier trap

Trammel nets
Trap entrance with V-shape passage; Composed of few small chambers tied to each other with V-shape passages; In Homa lagoon, the barrier trap is opened in December and closed in early June

Each 300-m long; with 3 different mesh sizes $(25,28$, and $30 \mathrm{~mm})$ with variable bar lengths inside nets; Hanging ratio $(E)$ was 0.50 for $100 \mathrm{~m}$ length of net 


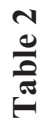

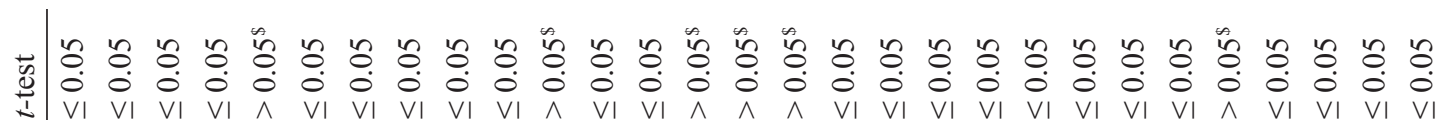
a a a a a a a a a a a a a a a a a a a a v vi vi

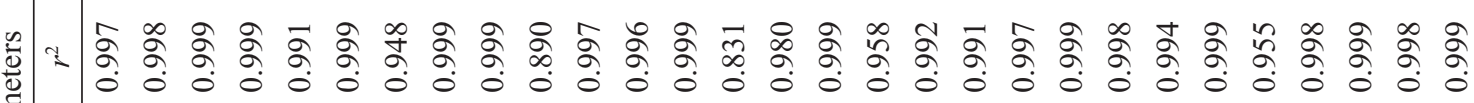

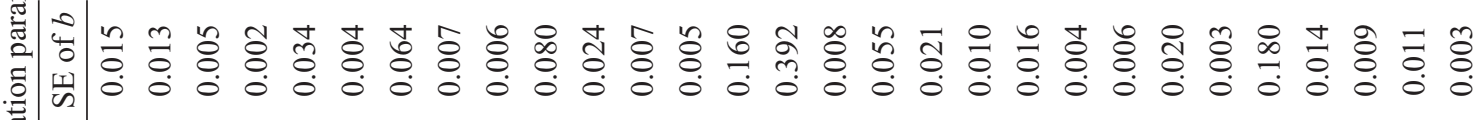

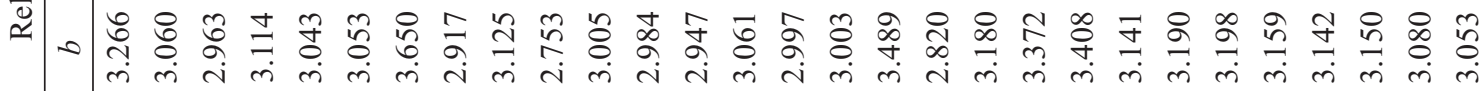

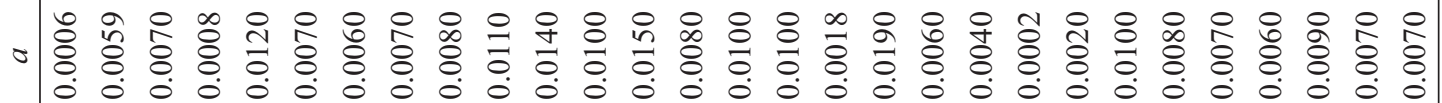

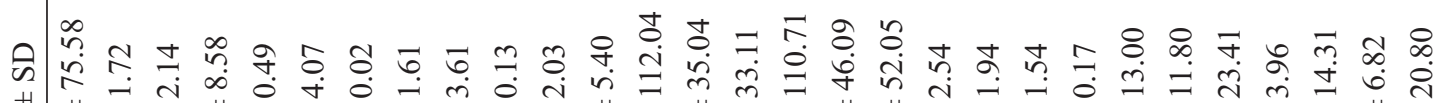

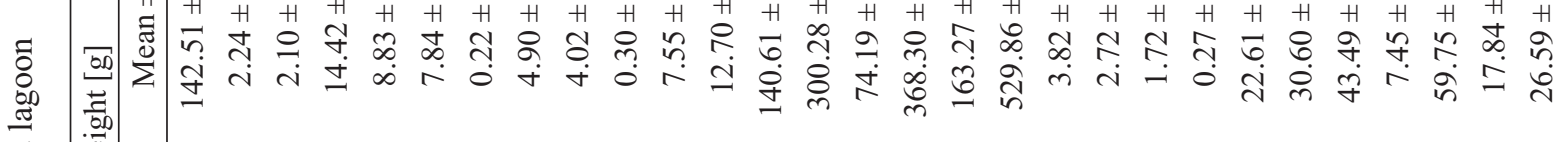

ڤ్రి

응

ఏ్ర

$\frac{\infty}{\mathscr{U}}$

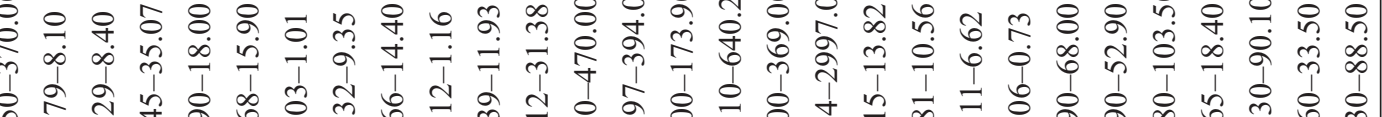

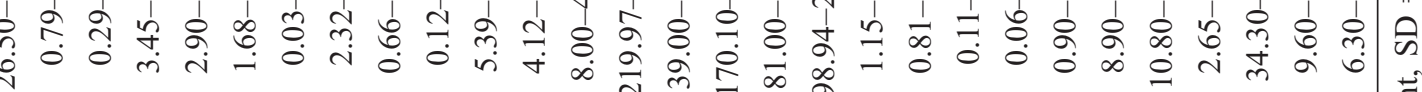

䨌

คิก

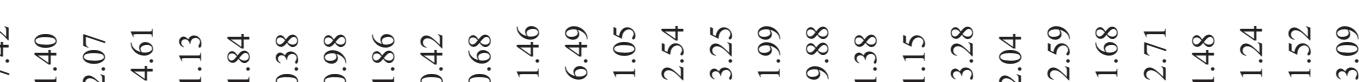

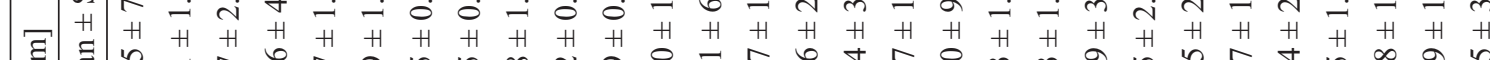
E



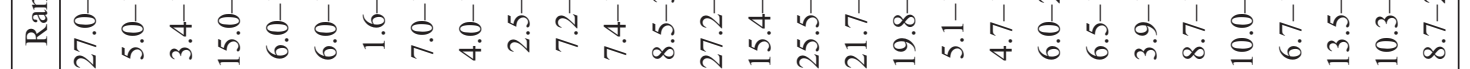

害

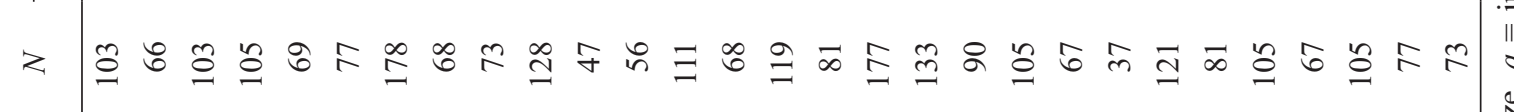

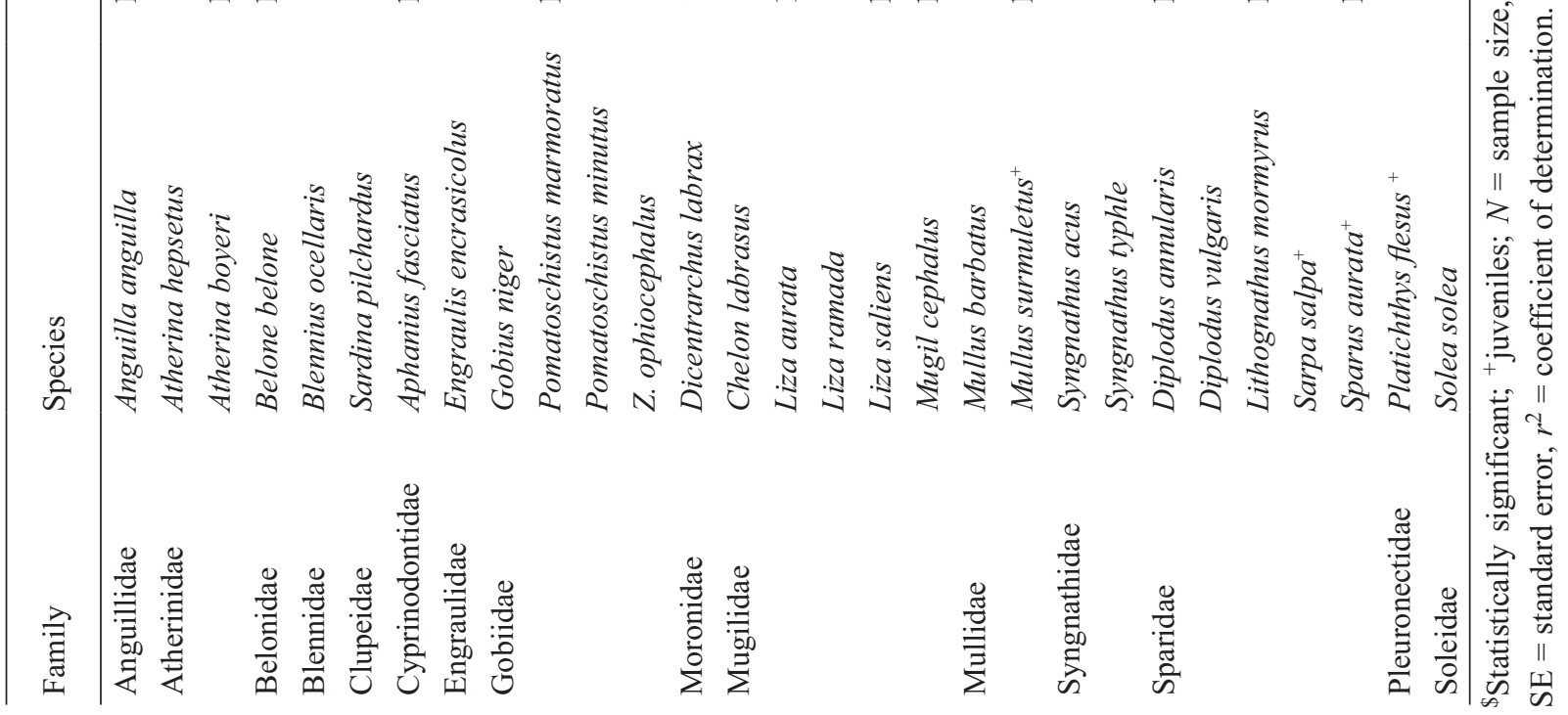


喜

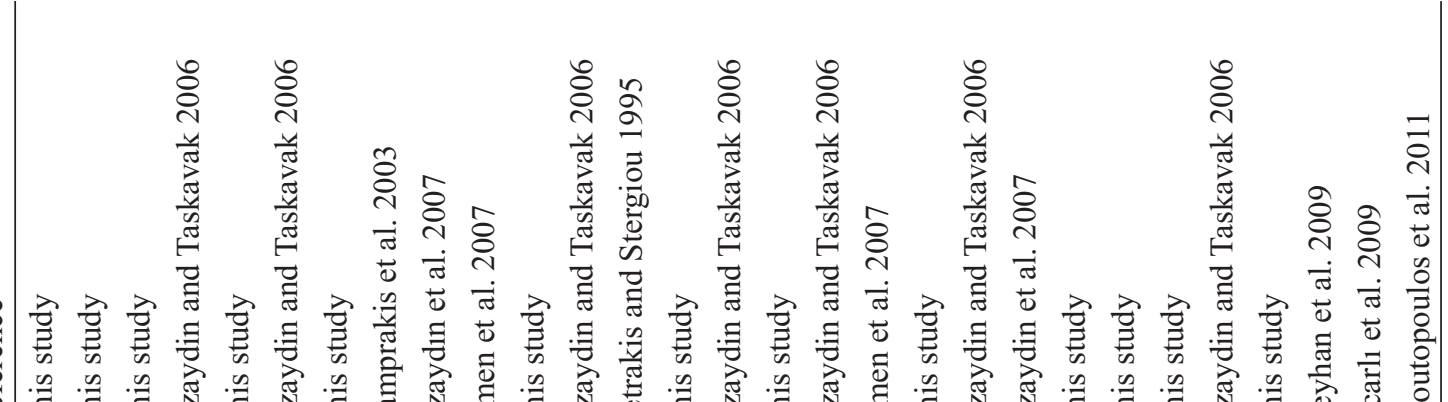

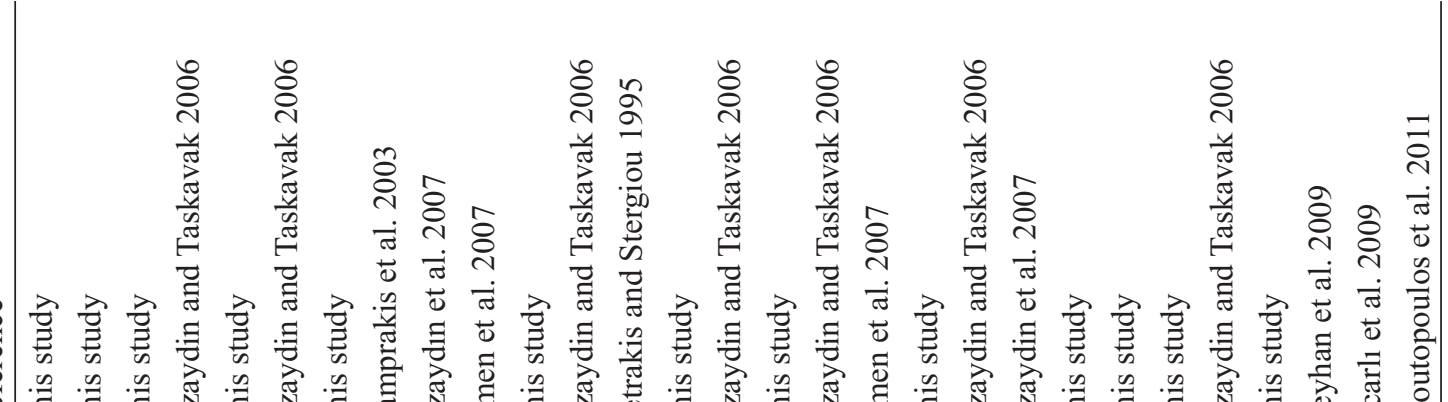

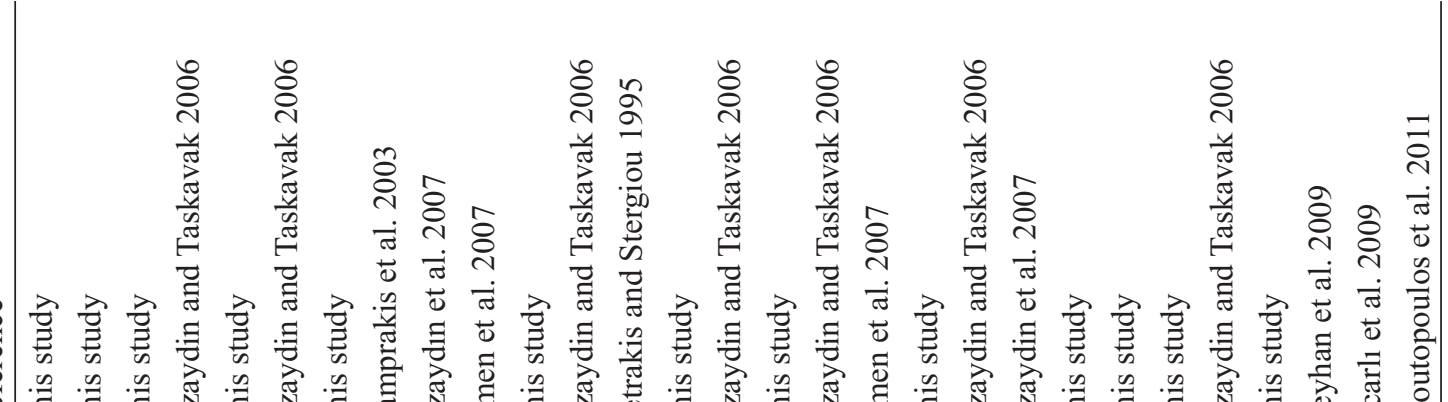

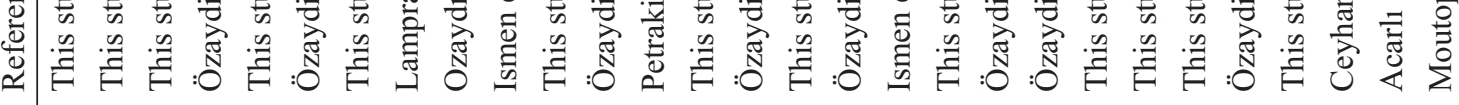

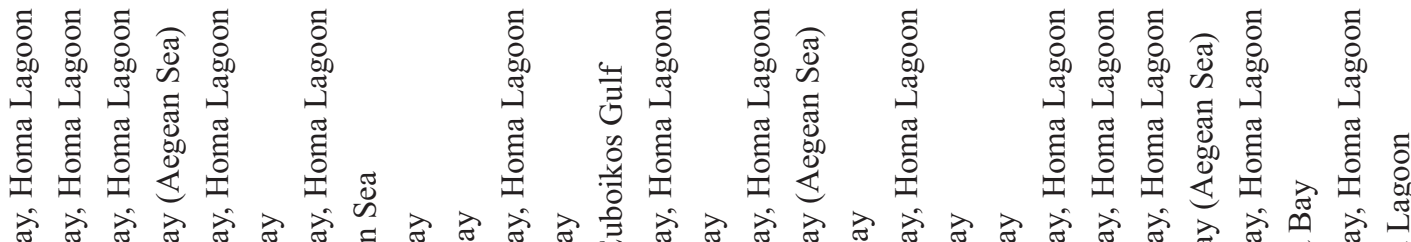

崩

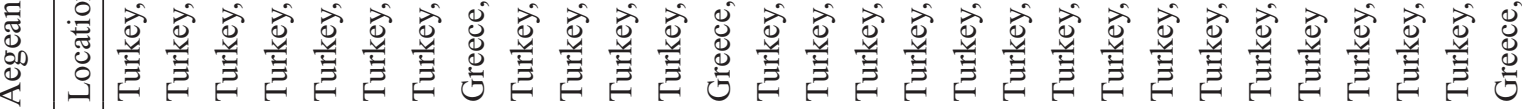

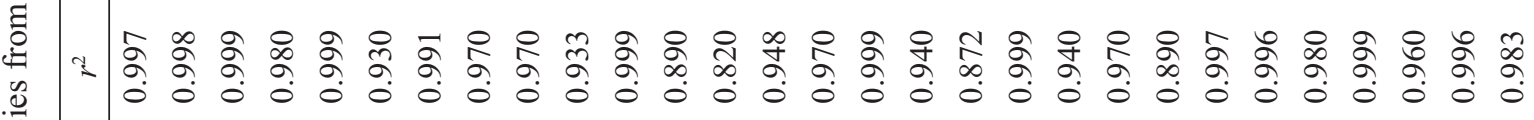

5

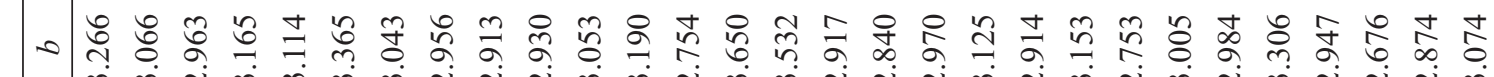

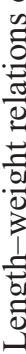

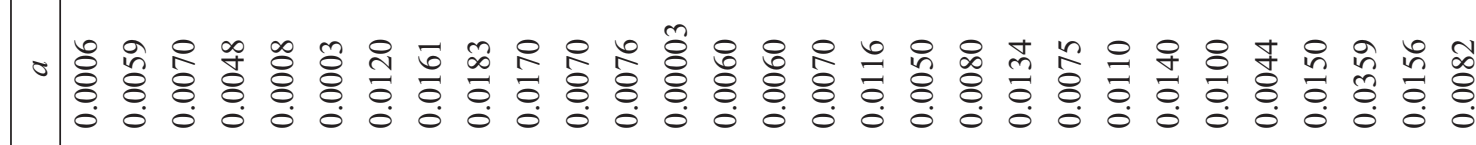

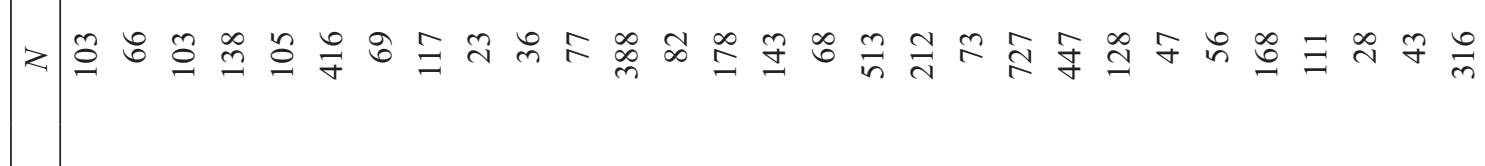

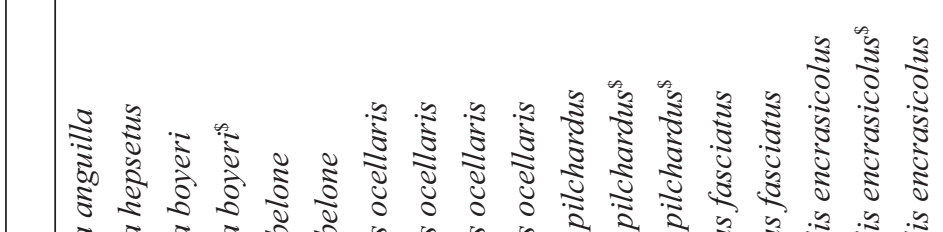

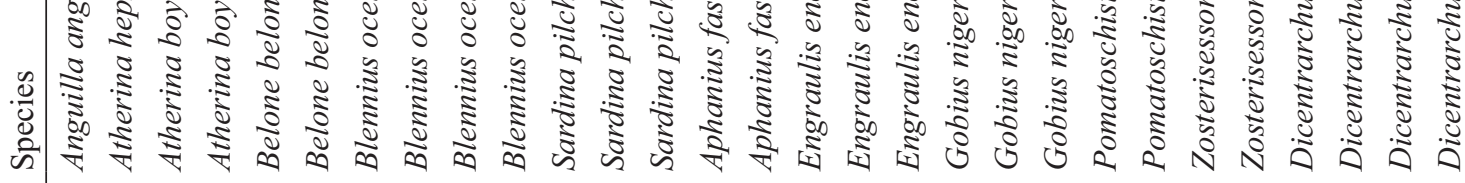

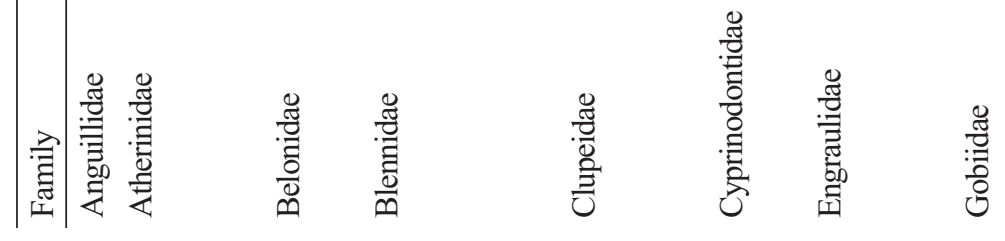

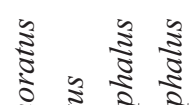

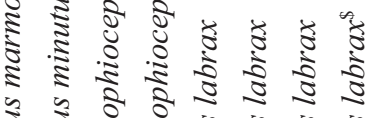




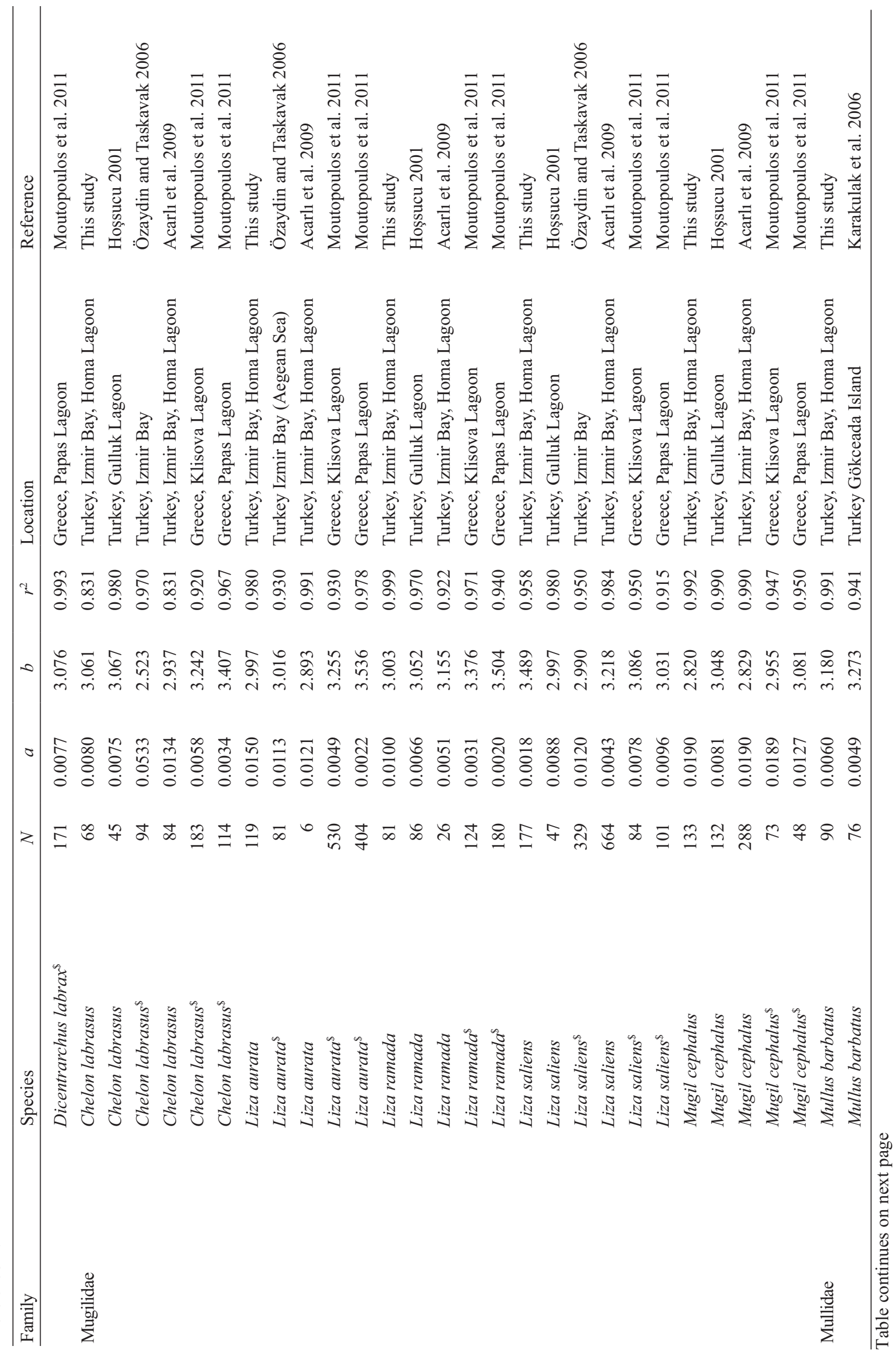




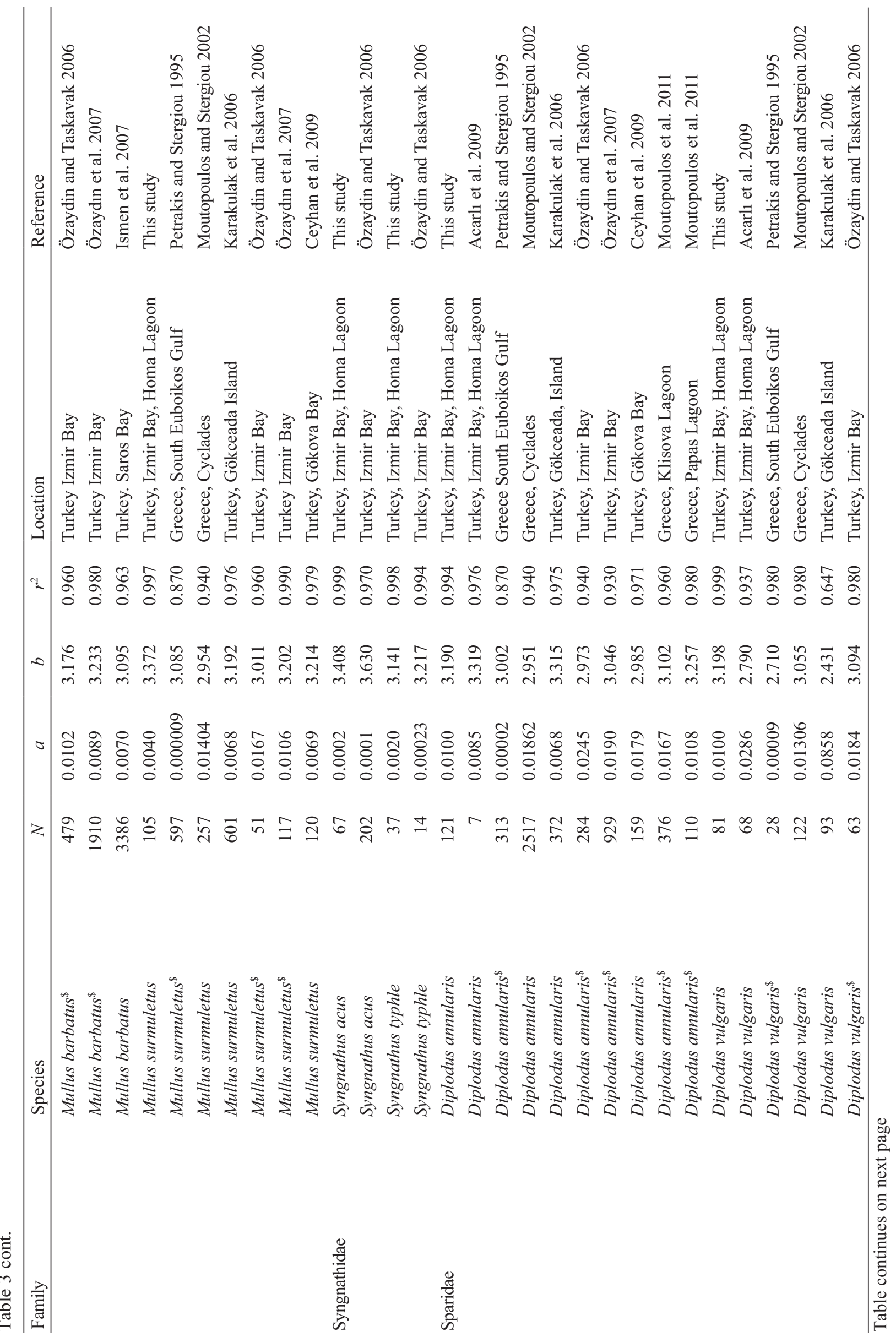




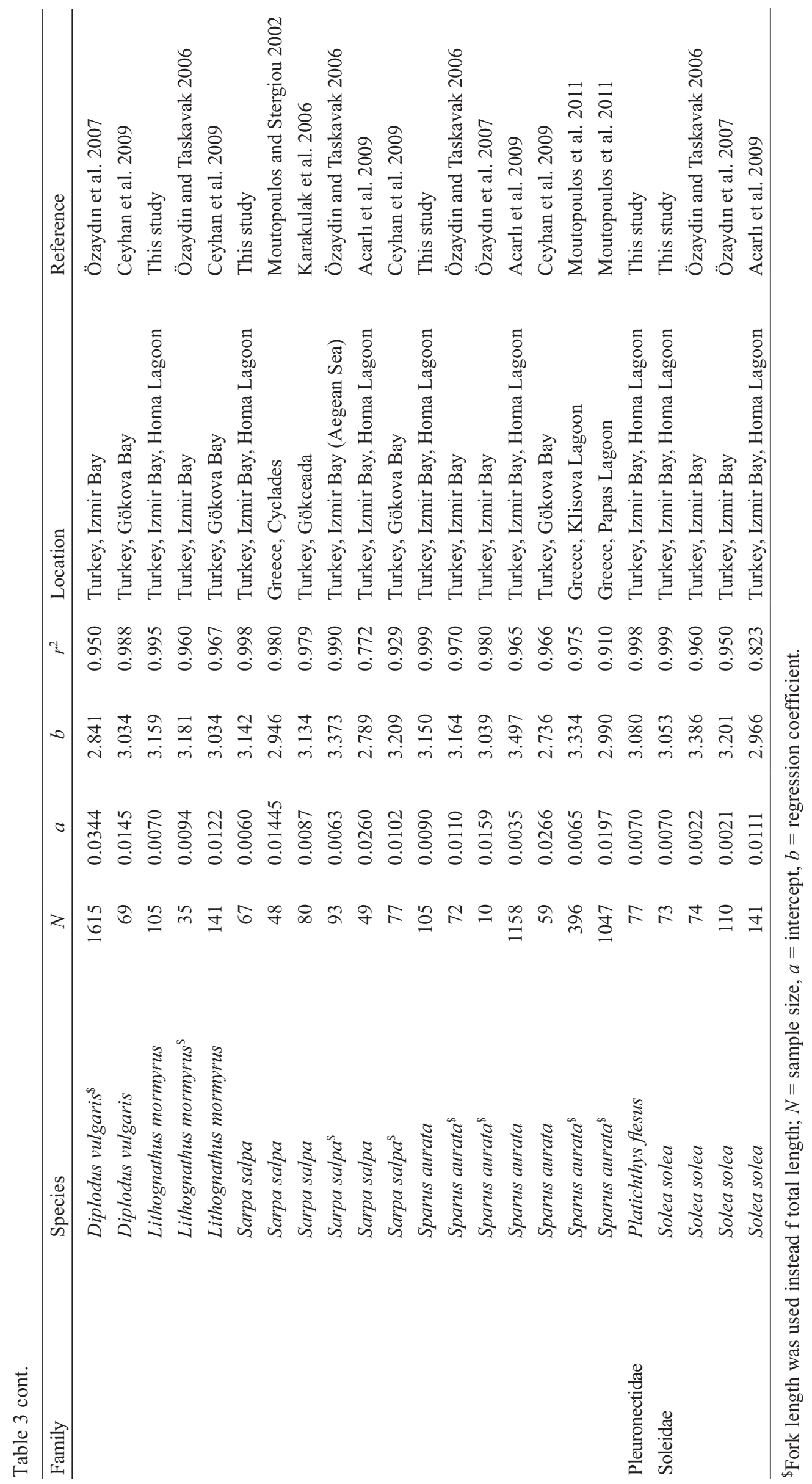


All allometric coefficients $(b)$ were within the expected range from 2 to 4 (Bagenal and Tesch 1978, Koutrakis and Tsikliras 2003). Values of $b=3$ indicate that the fish grow isometrically; values under or over 3 show an allometric growth. The exponent $b$ varied between 2.753 for Pomatoschistus marmoratus and 3.650 for Aphanius fasciatus with a mean value $b$ of 3.115 ( $\pm 0.068 \mathrm{SE})$. Four species showed isometric growth: Sardina pilchardus, Chelon labrasus, Atherina hepsetus, and Solea solea; 11 species presented negative allometric growth $(b<3)$ : Engraulis encrasicolus, Dicentrarchus labrax, Lithognathus mormyrus, Pomatoschistus marmoratus, Pomatoschistus minutus, Zosterisessor ophiocephalus, Blennius ocellaris, Liza aurata, Liza ramada, Mugil cephalus, and Atherina boyeri; and the remaining fish indicated positive allometric growth $(b>3)$ : Anguilla anguilla, Belone belone, Aphanius fasciatus, Syngnathus acus, Syngnathus typhle, Mullus barbatus, Mullus surmuletus, Diplodus annularis, Diplodus vulgaris, Sarpa salpa, Sparus aurata, Gobius niger, Liza saliens, and Platichthys flesus.

The coefficients of determination $\left(r^{2}\right)$ ranged between 0.831 for Chelon labrasus and 0.999 for eleven species (Table 2), corresponding to a mean value of $0.930( \pm 0.017 \mathrm{SE})$.

$\mathrm{L}-\mathrm{W}$ relations in fish are influenced by various parameters such as habitat, season, degree of stomach fullness, gonad maturity, sex, health, preservation techniques, and differences (Tesch 1971, Dulčić and Kraljević 1996, Wootton 1998, Verdiell-Cubedo 2006). Therefore, fish species of $b$ value in the same area can change at different year or period. In this study, $\mathrm{L}-\mathrm{W}$ parameters of five species (i.e., Anguilla anguilla, Atherina hepsetus, Pomatoschistus marmoratus, Pomatoschistus minutus, and Platichthys flesus were determined for the first time in the Aegean Sea (Table 3). In addition, the $b$ value of Blennius ocellaris, Aphanius fasciatus, Engraulis encrasicolus, Dicentrarchus labrax, Liza aurata, Liza saliens Mullus surmuletus, Diplodus vulgaris, and Lithognathus mormyrus were estimated higher than in other studies for Aegean Sea. Similar or lower results for $b$ value were found for other species in Table 3. Overall, the LW relations of the fish caught in lagoons are different between the Mediterranean and the Aegean Sea. The reason for this is the diversity of the fishing methods. In the Mediterranean lagoons such as Klisova and Papas in western Greece (Moutopoulos et al. 2011), Mar Menor Lagoon in Spain (Verdiell-Cubedo et al. 2006), the only one type of the fishing gear used was beach seine. In the presently reported study, four different fishing gear types were used (fyke nets, three trammel nets with different mesh sizes, barrier trap with $\mathrm{V}$ shape entrance, and beach seine). When $b$ value is compared between Greek lagoons and Homa Lagoon, the $b$ values of Mugilidae species in Klisova and Papas lagoons are higher than those reported presently by us. On the other hand, in both above-mentioned lagoons the $b$ value for Diplodus annularis was lower than the one form the presently reported study. The $b$ values of some fish species from the Mar Menor Lagoon (Engraulis encrasicolus, Gobius niger, Liza aurata, Liza ramada, Liza saliens, Lithognathus mormyrus, and Sarpa salpa), reported by Verdiell-Cubedo et al. (2006) were lower than our respective results. However some of the fish species as Pomatoschistus marmoratus, Chelon labrasus, Mugil cephalus, and Sparus aurata in Mar Menor Lagoon were higher than those presently reported from Homa Lagoon. Such differences in $b$ values can be associated with one or a combination of factors such as: the differences in the number of specimens examined, the area or/and season effects, the distinctions in the observed length ranges of the specimens caught, as well as the duration of the sampling periods (Moutopoulos and Stergiou 2002).

\section{ACKNOWLEDGEMENTS}

The authors would like express thanks to Mr. Sedat Tepeli, Mr. Ahmet Tepeli, and Mr. Bayram Ceylan for their invaluable contributions and helps with sampling processes in the area and to local fishermen Mr. Rasim Öztuz and Mr. Ridvan Öztuz. The authors are also grateful to the Ege University for its financial support.

\section{REFERENCES}

Acarlı D., Kara A., Bayhan B., Çoker T. 2009. Homa Lagünü'nden (İzmir Körfezi, Ege Denizi) yakalanan türlerin av kompozisyonu ve av verimi. ["Catch composition and catch efficiency of species caught from Homa Lagoon (Izmir Bay, Aegean Sea).'] Ege Journal of Fisheries and Aquatic Sciences 26 (1): 39-47. [In Turkish with English abstract.]

Alpbaz A., Kınacıgil T. 1988. İzmir Homa dalyanı'nın balık verimliliği ve balık faunası üzerine bir çalışma. [Study on fish fauna and fisheries efficiency of Homa Lagoon.] $\mathrm{Su}$ Ürünleri Dergisi (Ege Üniversitesi) 5 (17-18): 31-56. [In Turkish with English abstract.]

Bagenal T.B., Tesch F.W. 1978. Age and growth. Pp. 101-136. In: Begenal T. (ed.) Methods for assessment of fish production in fresh waters. 3rd edn. IBP Handbook No. 3. Blackwell Scientific Publications, Oxford, UK.

Bayhan B., Acarli D. 2006. Hermaphrodite thinlip mullet Liza ramada (Risso, 1810) (Teleostei: Mugilidae) from Homa Lagoon (Izmir Bay-Aegean Sea). Aquaculture Research 37 (10): 1050-1052. DOI: 10.1111/j.1365-2109.2006.01508.x

Ceyhan T., Akyol O., Erdem M. 2009. Length-weight relationships of fishes from Gökova Bay, Turkey (Aegean Sea). Turkish Journal of Zoology 33 (1): 69-72. DOI: 10.3906/zoo-0802-9

Dulčić J., Glamuzina B. 2006. Length-weight relationships for selected fish species from three eastern Adriatic estuarine systems (Croatia). Journal of Applied Ichthyology 22 (4): 254-256. DOI: 10.1111/j.1439-0426.2006.00633.x

Dulčić J., Kraljević M. 1996. Weight-length relationships for 40 fish species in the eastern Adriatic (Croatian waters). Fisheries Research 28 (3): 243-251. DOI: 10.1016/01657836(96)00513-9

Froese R., Pauly D. 1998. Fish Base 1998: Concepts, design and data sources. ICLARM, Manila, Philippines.

Gonçalves J.M.S., Bentes L., Lino P.G., Riberio J., Canário A.V.M., Erzini K. 1997. Weight-length relationships for selected fish species of the small-scale demersal fisheries of the south 
and south and southwest coast of Portugal. Fisheries Research 30 (3): 253-256. DOI: 10.1016/S01657836(96)00569-3

Hoşsucu B. 2001. Güllük Lagünü (Ege Denizi) kefal türlerinin (Mugil spp.) bazı büyüme özellikleri. [Some growth parameters of mullet species (Mugil spp.) living in Güllük Lagoon (Aegean Sea).] EU Journal of Fisheries and Aquatic Sciences 18 (3-4): 421-435. [In Turkish with English abstract.]

Ismen A., Ozen O., Altinagac U., Ozekinci U., Ayaz A. 2007. Weight-length relationships of 63 fish species in Saros Bay, Turkey. Journal of Applied Ichthyology 23 (6): 707-708. DOI: $10.1111 / j .1439-0426.2007 .00872 . x$

Karakulak F.S., Erk H., Bilgin B. 2006. Length-weight relationships for 47 coastal fish species from the northern Aegean Sea, Turkey. Journal of Applied Ichthyology 22 (4): 274-278. DOI: 10.1111/j.1439-0426.2006.00736.x

Katselis G., Koutsikopoulos C., Dimitriou E., Rogdakis Y. 2003. Spatial patterns and temporal trends in the fishery landings of the Messolonghi-Etoliko Lagoon (western Greek coast). Scientia Marina 67 (4): 501-511.

Koutrakis E.T., Tsikliras A.C. 2003. Length-weight relationships of fishes from three northern Aegean estuarine systems (Greece). Journal of Applied Ichthyology 19 (4): 258-260. DOI: 10.1046/j.1439-0426.2003.00456.x

Lamprakis M.K., Kallianiotis A.A., Moutopoulos D.K., Stergiou K.I. 2003. Weight-length relationships of fishes discarded by trawlers in the north Aegean Sea. Acta Ichthyologica et Piscatoria 33 (2): 145-151.

Le Cren E.D. 1951. The length-weight relationship and seasonal cycle in gonad weight and condition in the perch (Perca fluviatilis). Journal of Animal Ecology 20 (2): 201-219. DOI: $10.2307 / 1540$

Moutopoulos D.K., Koukou K., Vavarouta V., Ramfos A., Katselis G. 2011. Investigation of length-weight relationships for 10 commercial fish species as a possible trophic state index of coastal lagoons. Acta Adriatica 52 (2): 261-268.
Moutopoulos D.K., Stergiou K.I. 2002. Length-weight and length-length relationships of fish species of the Aegean Sea (Greece). Journal of Applied Ichthyology 18 (3): 200-203. DOI: 10.1046/j.1439-0426.2002.00281.x

Petrakis G., Stergiou K.I. 1995. Weight-length relationship for 33 fish species in Greek waters. Fisheries Research 21 (3-4): 465-469. DOI: 10.1016/0165-7836(94)00294-7

Ricker W.E. 1975. Computation and interpretation of biological statistics of fish populations. Bulletin of the Fisheries Research Board of Canada No. 191.

Özaydin O., Taskavak E. 2006. Length-weight relationships for 47 fish species from Izmir Bay (eastern Aegean Sea, Turkey). Acta Adriatica 47 (2): 211-216.

Özaydın O., Uçkun D., Akalın S., Leblebici S., Tosunoğlu Z. 2007. Length-weight relationships of fishes captured from Izmir Bay, central Aegean Sea. Journal of Applied Ichthyology 23 (6): 695-696. DOI: 10.1111/j.14390426.2007.00853.x

Sokal R.R., Rohlf F.J. 1981. Biometry. 2nd edn. Freeman, San Francisco, CA, USA.

Tesch W. 1971. Age and growth. Pp. 97-130. In: Ricker W.E. (ed.) Methods for assessment of fish production in fresh waters. 2nd edn. International Biological Programme, and Blackwell Scientific Publications, Oxford and Edinburgh, UK.

Verdiell-Cubedo D., Oliva-Paterna F.J., Torralva M. 2006. Length weight relationships for 22 fish species of the Mar Menor coastal lagoon (western Mediterranean Sea). Journal of Applied Ichthyology 22 (4): 293-294. DOI: 10.1111/j.1439-0426.2006.00738.x

Wootton R.J. 1998. Ecology of teleost fishes. Kluwer Academic Publishers, Dordrecht, the Netherlands.

Received: 16 December 2013

Accepted: 5 August 2014

Published electronically: 15 October 2014 